HARANGOZÓ Tamás ${ }^{1}$

\title{
AZ INTELLEKTUÁLIS TŐKE MÉRÉSE ÉS ENNEK LEHETSÉGES MAGATARTÁSI VONATKOZÁSAI
}

A cikk a szervezeti értékteremtésben megfigyelhetố változásokból kiindulva részletesen foglalkozik az intellektuális tốke tudatos, eredményes és hatékony irányításának, valamint fejlesztésének szükségességével. Mivel azonban mindez nem képzelhetố el a menedzsment tárgyát képezó eróforrásokról szóló valós és megbízható információk nélkül, ezért szintén bemutatásra kerül néhány, a nem tárgyiasult erôforrások mérésével foglalkozó menedzsmenteszköz, amelyek célja az intellektuális tóke szervezeti irányításba történố beemelése. Ezután szó esik a mérés gyakorlati megvalósítása során fellépố potenciális magatartási hatásokról, mégpedig abból a feltevésból kiindulva, hogy egy szakmailag tökéletesen megtervezett információs rendszer sem lehet sikeres az érintettek együttmúködése nélkül.

Kulcsszavak: immateriális javak, intellektuális tốke, mérési technikák

A nem tárgyiasult eróforrások mérése és szervezeti irányításba történő beemelése napjaink menedzsmentirodalmának egyik legtöbbet tárgyalt témaköre, amely intenzíven foglalkoztatja a szervezetek vezetése iránt érdeklődőket: úgy az elméleti, mint a gyakorlati szakembereket. A téma gyakorlati relevanciájáról erósen megoszlanak a vélemények, az azonban kétségtelen, hogy az intellektuális tő́ke versenyképességben és a vállalati értékteremtésben betöltött szerepének vizsgálata a mai közgazdaságtani és vezetéstudományi kutatások egyik legnépszerúbb területe.

Írásom elsố részében ez utóbbi tendenciához csatlakozom. Legfontosabb célom, hogy felhívjam a figyelmet a nem tárgyiasult eróforrások fontosságára a vállalati siker szempontjából, illetve bemutassak néhány fontosabb menedzsmenteszközt, melyek célja az intellektuális tốke szervezeti irányításba történó beemelése.

Nem mehetünk el azonban amellett sem, hogy a nem tárgyiasult értékek egyik legfontosabb hordozója éppen maga az ember. Ebból kiindulva a második részben megkísérlem felvázolni azokat az intellektuális tốke mérése során potenciálisan jelentkező magatartási hatásokat, amelyek figyelmen kívül hagyása, megközelítésem szerint, könnyen visszájára fordíthatja azt az egyébként méltányolandó törekvést, miszerint az intel- lektuális tóke és annak menedzselése elengedhetetlen, és a sikeres múködés egyik alapfeltétele.

\section{Trendek a szervezeti értékteremtés megítélésében - a nem tárgyiasult eróforrások szerepének növekedése}

A gyakorlati szakemberek számára az intellektuális tốke hatékony irányítása óriási kihívást jelent, annak ellenére is, hogy a nem tárgyiasult eróforrások kiemelkedő jelentőséggel bírnak napjaink társadalmában és gazdaságában egyaránt. A vállalatok egyrészt egyre jobban függenek az immateriális erőforrásoktól, másrészt minden iparágban egyre többet fektetnek intellektuális tókébe. Leonard Nakamura kutatása szerint például az amerikai magánvállalkozások csupán az 1980-as évektốl kezdődően összesen egytrillió dollárt fektettek nem tárgyiasult erőforrásokba (Nakamura, 2001. Idézi Lev, 2003: 5. o.).

A vállalatok könyv szerinti és piaci értéke között napjainkban megfigyelhetô óriási eltérés szintén jól illusztrálja a vállalatok értékét befolyásoló tényezókben bekövetkezett változásokat. Megállapítható ugyanis, hogy amíg korábban a vállalat értékének legnagyobb részét a materiális formát öltő gépek, épületek vagy 
más eszközök jelentették, addig ez a mai szervezetekról korántsem mondható el: az S\&P 500 vállalatainak átlagos könyv szerinti értéke 1978-ban például még átlagosan a piaci érték 95 százalékát tette ki, addig ma ez az arány alig éri el a 20 százalékot (Juhász, 2004: 5. o.). A legtöbb szerző e nagymértékú eltérést - egyebek mellett - az immateriális eróforrások szerepének növekedésével magyarázza, annak ellenére is, hogy ezen erőforrások csupán kevés esetben válnak láthatóvá a vállalati mérlegben, eredménykimutatásban, illetve a szervezet belsố jelentéseiben.

Az immateriális eszközök kiemelt szerepét hangsúlyozza Baruch Lev is, amikor azt állítja, hogy ezek - a képzett és gyakorlott munkaeró, a szabadalmak, a know-how, a szoftverek, a vevókapcsolatok, a márka, a szervezeti folyamatok és modellek stb. - eredményezik a vállalati növekedés és a részvénytulajdonosi érték legnagyobb részét, és ezekre vezethető vissza az USA-ban múködố részvénytársaságok piaci kapitalizációjának jóval több mint fele (Lev, 2004).

A vállalat eróforrás-alapú megközelitésének követói (Prahalad - Hamel, 1990) szintén a nem tárgyiasult erőforrásokat - pl. alkalmazottak készségei, szabadalmak vagy a vezetối tehetség - tekintik a legértékesebb stratégiai eróforrásoknak. Véleményük szerint - a különbözó tárgyi és pénzügyi eszközök mellett - ezekre építve lehet kiépíteni azokat az alapvető képességeket, amelyek aztán a vállalat hosszabb távú, jövóbeli sikerének motorjai lehetnek, hiszen legtöbbször értékesek, ritkák, nehezen másolhatók, és nem, vagy csak tökéletlenül helyettesíthetốk.

Ez utóbbi nézetet képviseli Gyökér Irén is, amikor azt mondja, hogy a ,szervezet stratégiai tókéjét az emberek képességei, az általuk kialakított vevôkapcsolatok, a márkákról a vevốben kialakított kép, a hatékony belső információs és kommunikációs rendszerek jelentik." (Gyökér, 2004: 49. o.) A gazdaságban és a társadalomban lejátszódó folyamatokból - globalizáció, technológiai forradalom, verseny kiéleződése, szolgáltató ágazat megerôsödése - kiindulva állítja, hogy nemcsak a high-tech ágazatokban, hanem a gazdaság valamennyi szektorában megfigyelhetố az intellektuális tôke jelentőségének növekedése. Példaként az acélipart, a légi közlekedést és a fogyasztási cikkek piacát említi, hisz míg az előbbiben fejlesztések révén jelentősen csökkenthető az egy fơre jutó bérköltség, addig a másodikban a helyfoglalási rendszer, míg a harmadik esetben a jól ismert márkanév jelenti a legfontosabb bevételi forrást. A szerzố emellett felhívja a figyelmet az immateriális vagyon mérésének nehézségeire is, és a számvitel Szent Gráljának nevezi a szellemi tóke értékelésének problémáját. Kiemeli, hogy a nem tárgyiasult erôforrások és képessé- gek - a többi eróforráshoz hasonlóan - csak akkor válhatnak versenyelốnnyé, ha a menedzsment képes azokat felismerni, hatékonyan alkalmazni és fejleszteni.

Az intellektuális tốke tulajdonosi, illetve fogyasztói értékteremtésben betöltött kiemelt szerepét azonban nemcsak az elméleti szakirodalom taglalja. A gyakorlati menedzsment szintjén megerôsíti például az az Egyesült Államokban végzett kutatás is, amelyben a megkérdezett vállalatok 84 százaléka szerint az utóbbi években nemcsak hogy nőtt az emberi erőforrás jelentôsége, hanem e trend erôsödését várták (Oliver, 2001. Idézi: Juhász, 2004).

Ezzel szinte teljesen megegyező eredményt hozott az a tudásmenedzsment magyarországi helyzetével foglalkozó 2005-ös felmérés, ahol a tudástókét a válaszadók 77 százaléka fontos stratégiai eszközként nevezte meg. A felmérésben részt vevő 130 szervezet szinte valamennyi iparágból képviseltette magát (KPMG-BME Akadémia - Pannon Egyetem, 2006).

A fentiek mellett a szellemi tóke társadalmi és gazdasági jelentőségét jelzi az eredeti formájában 2000ben kiadott Lisszaboni Határozat is, amely értelmében az EU átlagában K+F-re fordítandó összegnek 2007ig el kell érnie a GDP 3 százalékát, ezáltal elősegítve, hogy Európa a világ legdinamikusabb tudásalapú gazdaságává váljon. A határozat hangsúlyozza a vállalatok jelentős részvételét a folyamatban, a technológiát és a tudást nevezi a legfőbb sikertényezónek a termék- és szolgáltatás-előállításban, valamint kiemeli, hogy napjainkban a nem tárgyiasult eszközök a menedzselés fő tárgyai (RICARDIS, 2005).

\section{Az intellektuális tốke meghatározása}

Ahogyan a nem tárgyiasult erőforrásokra (,intan-gible assets") vonatkozóan többféle, e tanulmányban egymás szinonimájaként használt elnevezés (pl. intellektuális tóke, szellemi tóke, immateriális eszközök/javak, tudástóke stb.) használatos, a többféleség a fogalommal kapcsolatos definíciókra is igaz, hiszen nem alakult ki egységes, széles körben alkalmazott meghatározás az intellektuális tóke tartalmáról. A következókben ezért néhány fontosabb definíciót mutatok be az intellektuális tőke fogalmának tisztázása érdekében.

A szakirodalomban legtöbbször azokat az eróforrásokat értik nem tárgyiasult eszközök alatt, amelyek nem rendelkeznek materiális-fizikai, illetve pénzbeli megjelenési formával, azonban értékesek a vállalat számára (Kaufmann - Schneider, 2004; Arbeitskreis IWR, 2001 alapján).

Gu és Lev mindehhez - a kontextus szerepét hangsúlyozva - hozzáteszi, hogy a nem tárgyiasult erőfor- 
rások nem feltétlenül jelentenek értéket, hanem azáltal válnak azzá, hogy részt vesznek a vállalat értékteremtő folyamataiban. A szerzók a $\mathrm{K}+\mathrm{F}$-et, a marketing- és reklámtevékenységet, valamint a vállalat HR- és ITgyakorlatát tekintik a nem tárgyiasult értékek legfontosabb okozóinak (Gu - Lev, 2001).

Egy másik meghatározás szerint az intellektuális tőkét a vállalat azon eszközei jelentik, amelyek a tudásra épülnek. Ez a megközelítés azokat a szervezeti (belsô) jellemzốket emeli ki, mint az alkalmazottak tudása és tapasztalata, a szervezeti folyamatok vagy az információs rendszer. A külsố tényezók közül a márkaérték és a vevői bizalom kap hangsúlyt (Brennan - Connell, 2000).

A fentihez hasonló definíciót ad Edvinsson és Sullivan, amikor az intellektuális tôkét olyan tudásként definiálja, amely értékké konvertálható (Pfeil, 2004).

Mouritsen és szerzótársai a nem tárgyiasult tudástőkét fejlett belső folyamatokkal, teljesítménnyel, növekedéssel, valamint a minőség javulásával azonosítják. Megközelítésükben az intellektuális tóke az alkalmazottakban, a vevókben és a vevôkapcsolatokban, a folyamatokban és a támogató technológiákban, valamint e négy elem közötti interakciókban rejlik (Mouritsen et al., 2003).

$\mathrm{Az}$ Európai Unió Bizottsága által támogatott RICARDIS nevú kutatás, amely a tudástóke szerepét vizsgálja kutatásorientált kis- és középvállalatokban, az intellektuális tốkét a szervezet humán, szervezeti és kapcsolati tókéjeként és az ezekkel kapcsolatos tevékenységek kombinációjaként definiálja (RICARDIS, 2005: 4. o.).

Végül, de nem utolsósorban Kaplan és Norton - a Balanced Scorecard módszertan két atyja - az immateriális eróforrásokat a cég alkalmazottainak a vevơi szükségletek kielégítésére vonatkozó képességeinek összességeként határozza meg. Megközelítésükben a szellemi tókét emberi (képességek, tehetség), információs (információrendszerek, tudásalkalmazások, infrastruktúra) és szervezeti tókeelemek (kultúra, vezetés, összehangolás, teammunka) formájában megjelenő tudásként értelmezhetjük, amely azért létezik a szervezetben, hogy megkülönböztetô előnyt hozzon létre (Kaplan - Norton, 2005).

Mivel azonban a fenti definíciók túl általánosak ahhoz, hogy empirikus kutatások során használhassuk óket, ezért a legtöbb kutató az intellektuális tókét öszszetevôi segítségével határozza meg.

$\mathrm{Az}$ intellektuális tốke elemeinek egyik legjelentôsebb ilyen kategorizálását Edvinsson dolgozta ki a kilencvenes évek közepén. Megközelítésében a szellemi tớke két fő összetevốbôl áll, a humán tókéból és strukturális tókéból. A humán tớke azokat az emberi tényezóket jelenti, amelyek értéket teremtenek a vállalat számára, és szorosan kapcsolódnak az azt birtokló egyénhez vagy csoporthoz, így a szervezet nem képes tulajdonolni azokat. Ide tartoznak például az alkalmazottak képességei, kompetenciái, tudása, tapasztalata, a szervezet által fontosnak tartott értékek, a vállalati filozófia és kultúra is. A strukturális tôke ezzel szemben azokat a nem tárgyiasult értékeket tartalmazza, amelyeket az alkalmazottak minden este a cégben hagynak, miután hazamentek a munkából. A strukturális tốkét Edvinsson két további részre bontotta, az ún. vevói vagy ügyféltókére, valamint a szervezeti tókére. Elóbbibe a vevői piacokkal kapcsolatban keletkezett értékek (pl. ügyfélkapcsolatok, vevői elégedettség, piaci részesedés, elosztási csatornák, márka) tartoznak, míg utóbbit a szerző két újabb alkategória bevezetése révén határozta meg. Az innovációs tóke a vállalat és alkalmazottai révén létrehozott termék-, szolgáltatásés eljárásbeli innovációkat jelenti, míg a folyamattóke alatt a szerzố a szervezeti folyamatokat és struktúrát érti (Edvinsson, 2002; Gyökér, 2004).

Egy másik jól ismert - a fentihez nagyon hasonló - kategorizálás Karl-Erik Sveiby nevéhez fúződik, aki az immateriális vagyont a következő három csoportba sorolta (Sveiby 2001a; 2001b):

- Humán tóke: az alkalmazottak tudását, képességeit és kompetenciáit tartalmazza. A humán tốke tehát szorosan kapcsolódik az emberhez: a munkatársak belépésével érkezik, távozásuk esetén pedig elveszik a szervezet számára;

- Strukturális tóke (belsó szerkezet): ide tartoznak pl. a szervezeti folyamatok, rutinok, múködési modellek, IT-rendszerek, de a vállalati kultúra is. E tényezóket szintén az alkalmazottak hozzák létre, és rendszerint a vállalatok birtokolják. A belsố szerkezet és az emberek együttesen alkotják a szervezetet;

- Kapcsolati tóke (külsó szerkezet): a külsố szerkezet az ügyfelekkel és beszállítókkal kialakított kapcsolatokat és azok minôségét ragadja meg, de magában foglalja a márkanevet, védjegyeket, valamint a vállalat hírnevét és arculatát is.

A nem tárgyiasult erőforrások gyakorlati mérését elősegítendő kategorizálást dolgozott ki a fentiek mellett az „Immateriális Értékek a Számvitelben” elnevezésú munkacsoport, amikor egy hételemú osztályozást alkalmazott. Ez a megközelítés az előzőek egyfajta szintetizálásaként is értelmezhetô. Az egyes osztályok a következók: innovációs tóke, humán tóke, vevói tóke, szállitói tóke, befektetói tóke, folyamattóke, 
elhelyezkedési tóke (Arbeitskreis IWR, 2001). Ebben az osztályozásban az innovációs, a humán, a vevói és a folyamattóke tartalma megegyezik Edvinsson azonos nevú kategóriáival. A szállítói tốke a beszerzési oldalon kialakított kapcsolatokat (pl. a nyersanyagokhoz való hozzáférést) jeleníti meg, míg a befektetôi tóke a vállalat pénzügyi helyzetét írja le, azt, hogy milyen feltételek mellett képes tôkét - saját vagy idegen tốke formájában - bevonni a pénzpiacról. Az elhelyezkedési tốke a vállalat székhelyének területi elhelyezkedéséból adódik (pl. piacokhoz való hozzáférés stb.).

Noha a meghatározások sora még folytatható lenne, írásomban intellektuális tốke fogalma alatt összességében a szervezet materiális formával nem rendelkezó azon eróforrásait értem, amelyek részt vesznek az értékteremtésben, és valamilyen módon kapcsolódnak a tudáshoz. A szellemi tókét tehát értékké konvertálható tudásként tekintem, amely szorosan kapcsolódik a szervezet alkalmazottaihoz (humán tóke), folyamataihoz és struktúrájához (strukturális tóke), valamint a vevői, illetve a beszerzói piacokkal való kapcsolatához (kapcsolati tóke). Az intellektuális tóke általam is alkalmazott értelmezését jól illusztrálja az 1. ábra.

\section{Az intellektuális tốke összetevôi}

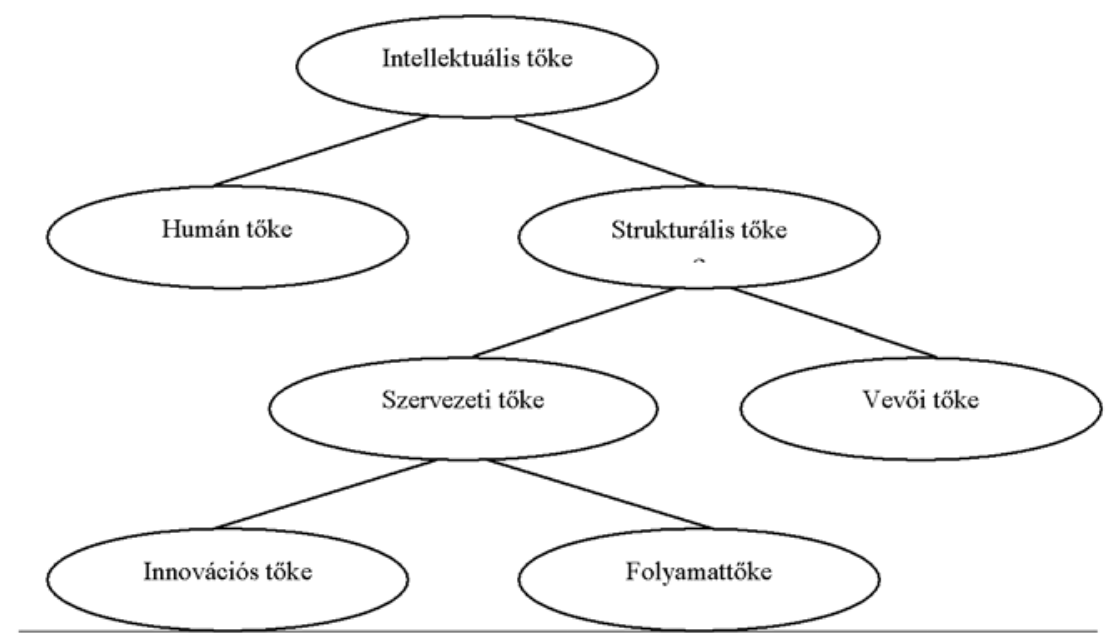

(Edvinsson, 2002: 83 o. alapján)

\section{Az intellektuális tốke mérése}

A szervezetekben és környezetükben lezajló folyamatokat (pl. a vállalatok piaci és könyv szerinti értéke között fennálló egyre növekvő eltérés, az intellektuális tốkebefektetések mértékének fokozódása, számos tudásmenedzsmenttel foglalkozó empirikus kutatás eredményei stb.) figyelembe véve belátható, hogy napjaink szervezeteiben a nem tárgyiasult eróforrások az értékteremtés egyik legfontosabb forrásai. Tudatos, eredményes és hatékony mérésük és fejlesztésük, valamint a szervezeti irányításba történó beemelésük ezért sok esetben a versenyképesség megszerzésének, illetve megtartásának alapfeltételei.

Ahhoz azonban, hogy bármely eróforrást hatékonyan tudjunk menedzselni, az elsô lépést az adott erôforrás számbavétele, jelenlegi helyzetének felmérése, valamint a kapott eredmény és a várható jövő́beli tendenciák összevetése jelenti. Ez igaz az intellektuális tốke kapcsán is. A következókben ezért röviden bemutatom a szellemi tóke mérésének legfóbb céljait és módszereit, majd rátérek a megvalósítás szempontjából szintúgy kritikus korlátozó tényezók tárgyalására. Mindenekelő́tt lássuk a nem tárgyiasult eszközök számbavétele kapcsán felmerülő legfő́bb célokat.

\section{A mérés legfontosabb céljai}

Ahogy korábban írtam, az intellektuális tóke számbavételének legfő́bb célja a nem tárgyiasult stratégiai erőforrások hatékony és eredményes menedzsmentjének lehetôvé tétele. Mindazonáltal a szakirodalomban többféle célkategorizálás is megtalálható.

\section{1. ábra}

Turner és Jackson-Cox (2002) például a mérés három célját azonosította, amelyek a következők: (1) az emberekbe fektetett tóke menedzselésének javitása, (2) a növekvó és csökkenố szellemi tókéjü cégek azonosítása, valamint (3) a vállalat szellemi befektetéseinek hosszú távú megtérülésmérése. A szerzók szerint az is fontos szempont, hogy a mérés ténye ráirányítja a vállalatvezetôk és a finanszírozók figyelmét a napjainkban kiemelten kezelendô nem tárgyiasult eszközcsoportokra. Ez utóbbival kapcsolatban Marr hozzáteszi, hogy a szellemi tő́ke mérésének elsődleges hozadéka, hogy a folyamat során azonosítják a tudástóke egyes elemeit.

A szerzố emellett kiemeli, hogy noha a pénz értékmérô szerepe vitathatatlan, a mérés során értelmetlen ragaszkodni az intellektuális tốke minden elemének pénzbeli értékeléséhez (Juhász, 2004).

$\mathrm{Az}$ intellektuális tóke számbavételének mögöttes mozgatórugóit Andriessen is vizsgálta, aki a mérés céljait tekintve három fő kategóriát különböztetett meg: (1) a belsốmenedzsment színvonalának növelését, (2) a külsó beszámolás fejlesztését, valamint (3) a törvényes elóírásoknak, illetve az üzleti elvárásoknak való megfelelést. Az elsố csoportba a szerzô megközelítésében 
olyan célok tartoznak, mint a menedzsmentkontroll hatékonyságának növelése, a különböző akciók hatásainak megértése és nyomon követése, egy - elsôsorban az intellektuális tókére épülő - erőforrás-alapú stratégia kialakítása, a stratégia konkrét akciókká konvertálása, valamint a nem tárgyiasult erőforrások menedzsmentjének fejlesztése. Külső célt képez többek között például a befektetớk irányában meglévő információs aszimmetria csökkentése, a vállalat értékének pontosabb bemutatása, a tốkevonzó képesség, valamint a szervezet reputációjának növelése is (Andriessen, 2004).

Végül a korábban említett RICARDIS kutatócsoport tagjai az intellektuális tốke számszerúsítésével kapcsolatban a következő fő célokat emelik ki (RICARDIS, 2005):

- az intellektuális tóke menedzsmentjének lehetővé tétele, a menedzseri döntéshozatal színvonalának javítása;

- teljesítményorientált szervezeti kultúra kialakítása, ahol jellemzó a tudás megosztása;

- a szervezet céljainak, tevékenységeinek valamint az üzleti modell jobb megértése;

- kvalifikált, tehetséges munkaerő vonzása, partnerség kialakítása más szervezetekkel, együttmúködés elôsegítése;

- a vállalatvezetés és a többi érintett közötti kommunikáció javítása;

- az átláthatóság növelése a részvényesek/tulajdonosok szemszögéból;

- a pénzügyi beszámolóban található információk kiegészítése a nem tárgyiasult erőforrásokról szóló adatokkal;

- a tốkepiac hatékony múködésének elősegítése, a tốkeallokációs döntések támogatása.

Látható tehát, hogy a szellemi tốke számbavétele mögött többféle célkitúzés is lehet, amelyek között szinte minden esetben kiemelt helyen szerepel a nem tárgyiasult értékek, a szervezet szellemi és tudástókéjének hatékony menedzselése, illetve az immateriális erőforrások által generált teljesítmény növelése.

\section{Az intellektuális tốke számbavételének fóbb módszerei}

Noha mára a nem tárgyiasult erőforrások egyes elemei a mérlegben is feltúnnek (szabályozásról lásd: 2000. évi C. tv. a számvitelról 25.§, 52-53.§, 57-59.§, 63.§ (1) és (2) bekezdés, valamint IAS 38.), megállapítható a szervezet pénzügyi és számviteli beszámolórendszerei nem teremtenek megfelelő alapot a nem tárgyiasult eróforrások számbavételére, valamint az általuk terem- tett érték kezelésére és mérésére. Mindez igaz annak ellenére is, hogy az eszközcsoport nem megfelelő kezelését a szakirodalom már évtizedek óta felrója a számvitelnek (bővebben lásd például Juhász, 2004).

A nem tárgyiasult eszközök értékteremtésben betöltött kiemelkedő szerepe következtében, valamint a számviteli információk hiánya miatt a menedzsmentszakirodalomban azonban többféle irányítási eszköz is megjelent az intellektuális tốke számbavétele kapcsán. Ezeket Sveiby széles körben elterjedt kategorizálása szerint az alábbi négy fó csoportba sorolhatjuk a mérés mögöttes módszertana alapján (Sveiby, 2002):

- közvetlen szellemi tóke (Direct Intellectual Capital - DIC) módszerek a szellemi tókét elemekre bontják, és az egyes részeket külön-külön értékelik monetáris szemléletben;

- piaci kapitalizáción alapuló (Market Capitalization Methods - MCM) módszerek az intellektuális tókét a vállalat piaci értéke és könyv szerinti értéke közötti különbségként határozzák meg;

- az eszközmegtérülési (Return on Assets - ROA) modellek a vállalat átlagos adózás előtti jövedelmét elosztják a tárgyiasult eszközök átlagos értékével, majd az iparági átlag felett elért hozam tốkésítése révén becslik a szellemi tốke értékét;

- a kimutatás alapú, ún. scorecard-típusú rendszerek (Scorecard Methods - SC) az egyes szellemi javak állományának leírására külön mutatókat határoznak meg, amelyek segítségével bemutatják a szellemi javak állományát és annak változását is. Az ide tartozó modellek jellemzóje, hogy nem elsődleges céljuk a pénzbeli érték meghatározása.

Figyelembe véve, hogy megközelítésemben az intellektuális tốke menedzsmentje nem feltétlenül követeli meg pénzben kifejezett információk rendelkezésre állását, valamint a késôbb tárgyalandó magatartási tényezók is kisebb valószínúséggel jelentkeznek a csupán pénzbeli értékelést megvalósító eszközök alkalmazása esetén (hiszen ezek általában valahol ,ott fent”, a szervezet pénzügyi osztályán készülnek), a következókben inkább a komplexebb menedzsmenteszközt is jelentő ún. scorecard-típusú modellekkel foglalkozom részletesen.

\section{A scorecard-típusú megközelítések}

E módszerek közös jellemzóje tehát, hogy nem törekszenek az intellektuális tốke és egyes elemeinek mindenképpen pénzben történő kifejezésére, hanem a vállalat szellemi tôkéjét különböző mutatók segítségével számszerúsítik. Céljuk a pénzbeli értékelés helyett jóval inkább: 
- a szellemi tốke változásának nyomon követése, strukturált formában történó bemutatása;

- a nem tárgyiasult eróforrások hatékonyabb szervezeti felhasználása és menedzselése;

- a rendelkezésükre álló emberi, strukturális és információs eróforrások mozgósítása;

- a stratégia szempontjából kritikus tudáselemek azonosítása;

- a szervezeti tudásmenedzsment, illetve a szükséges immateriális eszközök és képességek kifejlesztése;

- a versenyképesség növelése és az értékteremtés ok-okozati logika mentén történó támogatása (Juhász, 2004; Mouritsen - Bukh, 2003; RICARDIS, 2005).

1. táblázat

\section{Példák a nem tárgyiasult erốforrások} scorecard-típusú értékelésére

\begin{tabular}{|c|c|c|}
\hline $\begin{array}{l}\text { Módszer } \\
\text { elnevezése }\end{array}$ & Legföbb szerző & Típus \\
\hline $\begin{array}{l}\text { Human Capital } \\
\text { Intelligence }\end{array}$ & Jac Fitz-Enz (1994) & SC \\
\hline Skandia Navigator ${ }^{\mathrm{TM}}$ & Edvinsson \& Malone (1997) & SC \\
\hline $\begin{array}{l}\text { Value Chain } \\
\text { Scoreboard }^{\mathrm{m}}\end{array}$ & Lev B. (2002) & SC \\
\hline IC-Index ${ }^{\mathrm{Tm}}$ & $\begin{array}{l}\text { Roos, Roos, Dragonetti \& } \\
\text { Edvinsson (1997) }\end{array}$ & SC \\
\hline $\begin{array}{l}\text { Intangible Asset } \\
\text { Monitor }\end{array}$ & Sveiby (1997) & SC \\
\hline Balanced ScoreCard & Kaplan \& Norton (1992) & SC \\
\hline IC-Rating ${ }^{\text {IM }}$ & $\begin{array}{l}\text { Intellectual Capital Sweden AB } \\
(2002)\end{array}$ & SC \\
\hline $\begin{array}{l}\text { Intellectual Capital } \\
\text { Navigator }\end{array}$ & Stewart (1997) & SC \\
\hline $\begin{array}{l}\text { Intellectual Capital } \\
\text { Statement }\end{array}$ & $\begin{array}{l}\text { Danish Agency of Trade and } \\
\text { Industry (2000), Mouritsen et } \\
\text { al. (2003) }\end{array}$ & SC \\
\hline Wissensbilanz & $\begin{array}{l}\text { Österreichisches } \\
\text { Forschungszentrum Seibersdorf } \\
\text { (2001); Bundesministerium für } \\
\text { Wirtschaft und Technologie } \\
\text { Deutschland - Arbeitskreis } \\
\text { Wissensbilanz (2004) } \\
\end{array}$ & SC \\
\hline Wissens-Scorecard & Helm et al. (2004) & SC \\
\hline
\end{tabular}

A legfontosabb scorecard-típusú mérési rendszereket az 1. táblázat foglalja össze, a következókben példaként pedig azokat a gyakorlati esetben is alkalmazott módszereket mutatom be, amelyek lehetőséget biztosítanak az egyik legfontosabb intellektuális tốkeelem, mégpedig a humán tốke számbavételére is.
SKANDIA NAVIGATOR. A szellemi tóke rendszerszemléletû́ számbavételére elsóként az intellektuális tốkét a vállalaton belül már 1985 óta mérố svéd, biztosítási és pénzügyi szolgáltatásokat nyújtó Skandia tett kísérletet a kilencvenes évek közepén, kifejlesztve a Skandia Navigator nevú rendszerét. A munka irányítását a cég szellemitőke-igazgatójaként tevékenykedő Leif Edvinsson végezte.

A Skandia Navigator integrált és dinamikus megközelítésben kezeli és méri az intellektuális tóke egyes elemeit. Célja a döntéshozatal, a stratégiai és üzleti tervezés, valamint a kontroll újfajta, napjainkban igen relevánsnak számító információkkal történő támogatása (Skandia, 1999).

A modellben a szellemi tôke mérésére öt dimenzióban kerül sor, amelyek szorosan kapcsolódnak az intellektuális tốke Edvinsson-féle - korábban bemutatott kategorizálásához. Az öt mérési dimenzió a következő:

1. pénzügyi fókusz, amely a cash-flow generálóképességet méri;

2. ügyfélfókusz, amely révén információk nyerhető́k a vállalat és ügyfelei között fennálló kapcsolatokról;

3. folyamatfókusz, amely során azt mérik, hogy a technológia és a folyamatok mennyiben látják el támogató feladatukat az értékteremtés során;

4. a megújuláshoz és fejlódéshez kapcsolódó fókusz, amely a vállalat jövőbeli értékteremtố potenciáljáról ad képet;

5. az emberi eróforráshoz kapcsolódó fókusz, amely felhívja a figyelmet a vállalat humán tókéjére, illetve az alkalmazottak kiemelt szerepére az értékteremtés szempontjából (Juhász, 2004; Starovic - Marr, 2003).

A rendszer alaplogikáját a 2. ábra, míg az egyes szempontok mérésére alkalmazott mutatókat a 2. táblázat mutatja.

\section{Skandia Navigator ${ }^{\mathrm{TM}}$ logikai váza} (Edvinsson, 2002: 196 o.)

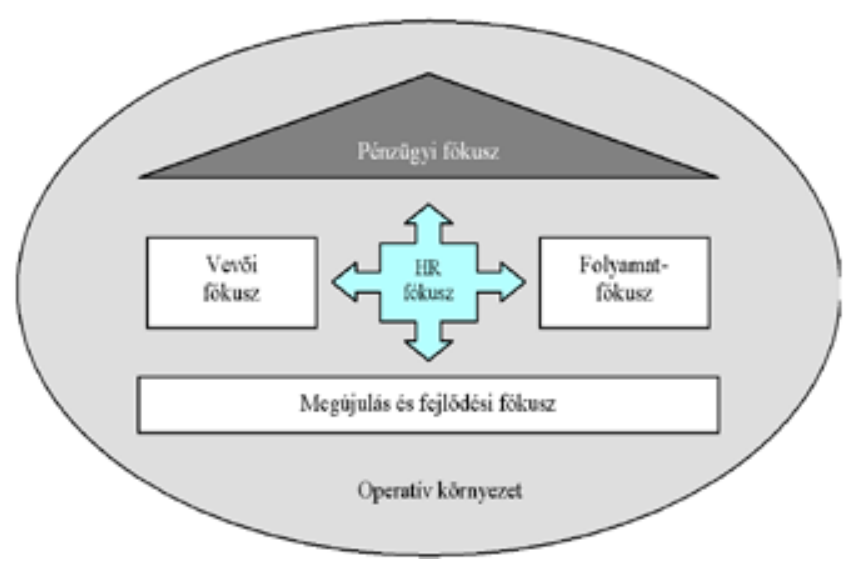


Példák a Skandia Navigator ${ }^{\mathrm{TM}}$-ban alkalmazott mutatókra

(Bontis, 2001: 46 o.)

\begin{tabular}{|l|l|}
\hline $\begin{array}{l}\text { Pénzügyi } \\
\text { fókusz }\end{array}$ & $\begin{array}{l}\text { • Árbevétel/alkalmazottak száma } \\
\text { • Ujj vevőktől származó árbevétel/összes árbevétel } \\
\text { - Ujj üzleti tevékenységbőll származó nyereség }\end{array}$ \\
\hline Vevői fókusz & $\begin{array}{l}\text { - Ügyféllátogatásra fordított napok száma } \\
\text { - Megnyert/elveszített ügyfelek aránya (\%) }\end{array}$ \\
\hline $\begin{array}{l}\text { Folyamatfó- } \\
\text { kusz }\end{array}$ & $\begin{array}{l}\text { - Egy alkalmazottra jutó PC-k száma } \\
\text { - Feldolgozacitás (CPU) }\end{array}$ \\
\hline $\begin{array}{l}\text { Megújulás } \\
\text { és fejlődési } \\
\text { fókusz }\end{array}$ & $\begin{array}{l}\text { - Elégedett alkalmazott index } \\
\text { - Tréningköltségek/adminisztratív költségek (\%) }\end{array}$ \\
\hline $\begin{array}{l}\text { Humán } \\
\text { fókusz }\end{array}$ & $\begin{array}{l}\text { - Felsőfokú végzettségű menedzserek száma } \\
\text { - Személyzet éves forgása (\%) }\end{array}$ \\
\hline
\end{tabular}

ternatív megoldást Sveiby az IAM megalkotásával (van den Berg, 2002).

A módszer az intellektuális tốkét humán, strukturális és kapcsolati tôkkeelemek összességeként tekinti, ezért a modellben szereplő - pénzügyi és nem pénzügyi - mutatók a szellemi tốkét szintén e tényezók számszerú formában történő megragadása révén határozzák meg, az alábbi három fó jellemzốre fókuszálva: növekedés/megújulás, hatékonyság és stabilitás (Sveiby, 2001c). A modellt a 3. ábra mutatja.

INTELLECTUAL CAPITAL STATEMENT. Az Intellectual Capital Statement (ICS) modellt Mouritsen és munkatársai dolgozták ki a Dán Tudományos, Technológiai és Innovációs Minisztérium megbízásából, elôsegítendô, hogy a dán vállalatok és más szervezetek hatékonyabban használják fel nem tárgyiasult eróforrásaikat, és - elsôsorban tudásmenedzsmentjük fejlesztése révén - növeljék verseny- és értékteremtô képessé-

Intangible Assets Monitor - mutatók a gyakorlati életben

(Bontis, 2001: 53 o. és Starovic-Marr, 2003: 12. o.)

\begin{tabular}{|c|c|c|c|}
\hline \multicolumn{4}{|c|}{ Nem tárgyiasult erőforrások mérése } \\
\hline & $\begin{array}{c}\text { Belső szerkezet } \\
\text { (Strukturális tóke) }\end{array}$ & $\begin{array}{l}\text { Külső szerkezet } \\
\text { (Kapcsolati tóke) }\end{array}$ & $\begin{array}{l}\text { Kompetencia } \\
\text { (Humán tóke) }\end{array}$ \\
\hline $\begin{array}{l}\text { Növekedés/ } \\
\text { Megújulás }\end{array}$ & $\begin{array}{l}\text { - IT-beruházások } \\
\text { - K+F átfutási ideje } \\
\text { - Új termékekből származó árbevétel }\end{array}$ & $\begin{array}{l}\text { - Árbevétel növekedése } \\
\text { - Piaci részesedés növekedése } \\
\text { - Elégedett ügyfelek aránya }\end{array}$ & $\begin{array}{l}\text { - Átlagos szakmai tapasztalat (év) } \\
\text { - Felsőfokú végzettséggel rendelkező } \\
\text { szakértők száma }\end{array}$ \\
\hline Hatékonyság & $\begin{array}{l}\text { - Adminisztratív személyzet aránya } \\
\text { - Bevételek/adminisztratív } \\
\text { személyzet }\end{array}$ & $\begin{array}{l}\text { - Egy vevőre jutó nyereség } \\
\text { • Értékesítés/alkalmazottak száma }\end{array}$ & $\begin{array}{l}\text { - Egy szakértőre jutó hozzáadott érték } \\
\text { - Egy alkalmazottra jutó hozzáadott érték } \\
\text { - Hozzáadott érték változása /alkalma- } \\
\text { zottak száma }\end{array}$ \\
\hline Stabilitás & $\begin{array}{l}\text { - Fluktuáció az adminisztratív } \\
\text { személyzet körében } \\
\text { - Szenioritás } \\
\text { - Újoncok aránya }\end{array}$ & $\begin{array}{l}\text { - Vevői elégedettség indexe } \\
\text { - Többszöri megrendelések száma } \\
\text { - Öt legnagyobb vevő }\end{array}$ & $\begin{array}{l}\text { - Elégedettségi index } \\
\text { - Alkalmazottak fluktuációja } \\
\text { - Átlagéletkor }\end{array}$ \\
\hline
\end{tabular}

INTANGIBLE ASSETS MONITOR. A Celemi nevú svéd vállalatnál alkalmazott Intangible Assets Monitor (IAM) szintén fontos, a nem tárgyiasult eszközök számbavételét és strukturált bemutatását szolgáló eszköz. A modellt Sveiby fejlesztette ki a kilencvenes évek közepén (Starovic - Marr, 2003).

A megközelítés szerint a vállalat piaci értéke a látható vagyon, azaz a tárgyiasult eszközök és a - három összetevớból álló és láthatatlan - nem tárgyiasult erőforrások értékének összegéból adódik. Míg azonban az elóbbiek jól közelíthető́k a könyv szerinti értékkel, addig az intellektuális tókeelemek értékének meghatározása korántsem ilyen egyszerú, annak ellenére, hogy ezek jelentik a piaci és könyv szerinti érték eltérésének legnagyobb részét. A nem tárgyiasult erőforrások mérésére kínál al- güket. A módszer egyszerre jelent menedzsmenteszközt, amely ráirányítja a vezetók figyelmét a tudás értékteremtésben betöltött kiemelt szerepére, és releváns információkkal segíti a vállalat tudásmenedzsmentjét, valamint kommunikációs eszközt, amellyel fontos üzenetek juttathatók el az alkalmazottakhoz, a vevókhöz, az együttmúködő partnerekhez és a befektetốkhöz arról, hogy vállalatuk miként teremt értéket a számukra (Mouritsen et al., 2003).

A megközelítés, melynek célja az értékteremtés okokozati logika mentén történő támogatása, az intellektuális tốkét négy összetevớre bontja, és a tudástốkét az alkalmazottak tudásából, a vevókapcsolatokból, a folyamatokból, a technológiákból és e négy tényezó közötti interakciókból eredezteti. 
Az Intellectual Capital Statement a kontextus szerepét is figyelembe véve (1) egyrészt alkalmas mutatókat szolgáltathat a nem tárgyiasult erôforrások mérése és értékelése érdekében, (2) másrészt strukturált módon mutatja be az intellektuális tóke elemeit és azok kölcsönhatásait, ezáltal elôsegítve a tudás mint eróforrás jobb megértését; (3) harmadrészt támogathatja a vállalat tudásmenedzsment-stratégiájának kifejlesztését is.

A modell alapelemeit és logikáját konkrét példa segítségével a 4. ábra mutatja. tásban kezeli, ami szinte teljesen megegyezik Sveiby korábban bemutatott kategorizálásával.

Az Intellectual Capital Navigator mindhárom fenti intellektuális tókeelemhez három mutatót javasol, azonban - Sveiby Intangible Assets Monitor modelljével ellentétben - nem tesz különbséget a növekedés/megújulás, hatékonyság és stabilitás szempontjai között, hanem implicit módon az IAM-ban is szereplő növekedés/megújulási aspektusra fókuszál.

A modellrôl elmondható, hogy elsődleges célja az 4. ábra intellektuális tôkében bekövetkezett változásoknak, illetve magának a szellemi tókének grafikus módon történó ábrázolása, valamint a piaci és könyv szerinti érték eltérésének bemutatása. Emellett lehetôvé teszi a tudástốke jelenlegi helyzetének értékelését, a célok kijelölését, valamint a terv-tény értékek figyelembevétele révén a korábbi céloktól való eltérés elemzését is, ezáltal elősegítve a beavatkozási szükségletek azonosítását (North - Probst - Romhardt, 1998; Schönleber, 2005 alapján). A modell grafikus felülete az 5. ábrán látható.
Az Intellectual Capital Navigator grafikus felülete (North-Probst-Romhardt, 1998: 162 o.)

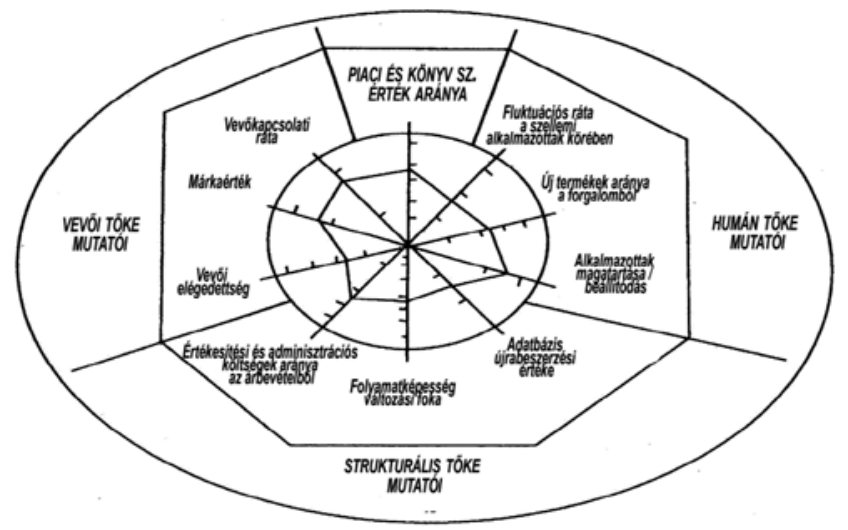

INTELLECTUAL CAPITAL NAVIGATOR. Kifejlesztése Stewart (1997) nevéhez fúződik. A modell a szellemi tôkét humán, strukturális és vevôi tôke bon-
IC INDEX. A modellt, amely az intellektuális tôkét számszerúsíteni igyekvő scorecard-típusú módszerek egyik második generációs példájának tekinthető, Roos és szerzótársai fejlesztették ki 1997-ben.

A modell a tudástókét három fó kategóriába - a szerzók által Intellektuális Tóke Fának nevezett ábrába rendezi, megkülönböztetve a humán tôkét, a szervezeti tôkét, valamint a vevői és kapcsolati tôkét. A szervezeti tôkét ezután tovább bontja az ún. megújulási és fejlődési, valamint folyamattókére (Van den Berg, 2002).

Az IC Index emellett kísérletet tesz az egyes - különböző szempontokat képviselő - mutatóknak egy közös, összefoglaló mutatóba súrítésére, illetve megpróbálja az intellektuális tôkében bekövetkező változásokat öszszekapcsolni a piaci változásokkal is (Bontis, 2001).

A módszertanra folyamatmegközelítés és négy nézőpont - ezek: kapcsolati, humán, infrastrukturális, in- 
novációs - alkalmazása jellemző. A folyamat lépései pedig a következók (Van den Berg, 2002: 21. o.):

1. a meglévô mutatók kritikus áttekintése, felülvizsgálata.;

2. az egyes IC-kategóriák között „flow” kapcsolatokat megragadni képes mutatók kifejlesztése;

3. a mutatók hierarchiájának kialakítása.

A módszer minden nézóponthoz több mutatót is ajánl, amiket ezután négy indexben foglalhatunk össze, ezáltal számszerúsítve a tudástốke egyes elemeit. Az indexek egymáshoz való viszonyát és konkrét tartalmát a 6. ábra tartalmazza.

múlt eseményeinek azonnal mérhetô gazdasági következményeiról, és megmutatják, hogy a stratégia megvalósítása hozzájárul-e a vállalat jövedelmezôségéhez. A mutatók elsôsorban az üzemi/üzleti eredményhez, múködő tốkére jutó hozamhoz, vagy a hozzáadott értékhez kapcsolódnak.

- Vevói nézốpont: ebben a nézôpontban kerülnek azonosításra a fogyasztói célszegmensek, valamint meghatározódnak a teljesítmény mérószámai is a kiválasztott célpiacok vonatkozásában. Itt kerülhet sor az Edvinsson által vevói tókének nevezett tudástốkeelemek számbavételére.

\section{6. ábra}

Az IC-Index kategóriái - hierarchia és mutatók (Van den Berg, 2002: 21. o.)

\begin{tabular}{|l|l|}
\hline Kapcsolati Tőke Index & Humán Tőke Index \\
- Kapcsolatok számának növekedése & - Kulcssikertényezők teljesítése \\
- Bizalomnövekedés & - Egy alkalmazottra jutó értékteremtés \\
- Vevőmegtartás & Tréninghatékonyság és -hatásosság \\
- Elosztási csatorna hatékonysága és minősége & \\
\hline $\begin{array}{l}\text { Infrastrukturális Tőke Index } \\
\text { - Hatékonyság }\end{array}$ & $\begin{array}{l}\text { Innovációs Tőke Index } \\
\text { - Hatásosság }\end{array}$ \\
- Kulcsüzlet-generálási képesség \\
- Elosztási hatékonyság & - Jó termékek előállításának képessége \\
\hline
\end{tabular}

Múködésifolyamatok nézópontja: ebben a nézópontban kerülnek meghatározásra és jellemzésre azok a kritikus folyamatok, amelyekben a szervezetnek kiemelkedő teljesítményt kell nyújtania a vevók igényeinek kielégítése érdekében. Itt számszerúsítik tehát az intellektuális tớke Edvinsson kategorizálásában folyamattókének nevezett összetevőjét.

- Tanulási és fejlôdési nézópont: ez a nézópont jeleníti meg azt az infrastruktúrát, amelyet a szerve-

BALANCED SCORECARD. Noha a Balanced Scorecard (BSC) módszertan, melyet Kaplan és Norton fejlesztett ki a '90-es évek közepén, elsődleges célja nem a szellemi tốke mérése és számszerúsítése, mint átfogó stratégiai menedzsmenteszköz meglehetôsen tág teret biztosít az intellektuális tôke figyelembevételéhez, hiszen nézôpontjai révén egyrészt elôsegíti a stratégiai célok eléréséhez szükséges tudástốkeelemek azonosítását és fejlesztését, másrészt az állapotukban bekövetkezett változások nyomon követését is támogatja. Ebben a megközelítésben a BSC tehát a kifejezetten a szellemi tókét számba vevố modellek egyik előfutáraként is tekinthető (North - Probst - Romhardt, 1998).

A Balanced Scorecard a stratégia lebontása során a szervezetet négy nézópontból közelíti meg. Ezek egyensúlyt teremtenek a rövid és hosszú távú célok között, valamint a kemény, objektív mérôszámok valamint a puha, szubjektívebb teljesítményokozók között. A négy - egymással ok-okozati viszonyban lévő - nézốpont a következő (KaplanNorton, 1996 alapján):

- Pénzügyi nézópont: az ide tartozó mutatók összefoglaló információkkal szolgálnak a zetnek ki kell alakítania a hosszú távú növekedés és fejlődés biztosítása érdekében, itt kerülnek azonosításra a jelen és a jövő sikertényezői. Kaplan és Norton szerint e nézópontban három fó kategória szerepel, mégpedig (1) az alkalmazottak képességei, (2) az információrendszerek, valamint (3) a motiváció, meghatalmazás és összhang. Edvinsson megközelítése szerint e nézőpontban történik meg a humán, szervezeti és innovációs tókeelemek számbavétele (7. ábra).

7. ábra

A Balanced Scorecard négy nézôpontja

(Kaplan és Norton, 1996. 20. o.)

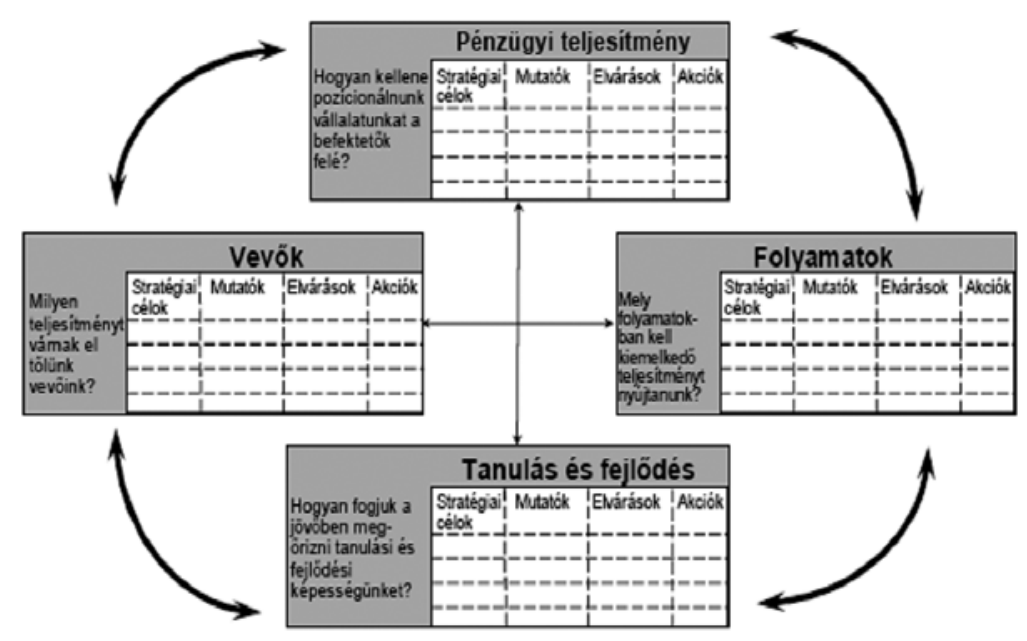




\section{A mérési módszerek korlátai - kihívások a megvalósítás során}

Ahogy az 1. táblázat is mutatja, az intellektuális tốke számbavételével többféle módszertan foglalkozik. A gyakorlati megvalósítás során a szervezetek azonban többféle kihívással és problémával szembesülhetnek, amelyek következtében egyrészt megkérdőjeleződhet a kapott érték megbízhatósága, másrészt adott esetben a teljesítmény csökkenését előidézố negatív szervezeti hatások is felléphetnek.

Kaplan és Norton megközelítésében emellett az intellektuális tôke mérését és menedzselését az is megnehezíti, hogy az általuk elérhetố értékteremtés alapvetôen eltér a materiális, fizikai és pénzügyi eszközökre jellemző értékteremtéstốl. A szerzók négy fő korlátozó tényezőt emelnek ki a nem tárgyiasult erőforrások értékteremtő képességét vizsgálva (Kaplan - Norton, 2005):

1. Az értékteremtés indirekt, azaz nem, vagy csak ritkán közvetlen, hanem inkább ok-okozati kapcsolatok láncolatán keresztül valósul meg.

2. Az érték környezetfüggó, azaz az immateriális eszközök stratégiával való összehangolásának mértékétôl függ.

3. Az érték potenciális, azaz az intellektuális tókébe fektetett erőforrások költsége csupán gyenge közelítése az értéknek. Az érték nem elsôsorban a befektetés költségétôl, hanem a tudástốke jövôbeli felhasználásától függ, így adott esetben nagyobb vagy kisebb is lehet a bekerülési költségeknél.

4. Az immateriális eszközök szorosan összekapcsolód$n a k$, azaz a stratégiától és más szervezeti összefüggéseiktôl független értékük általában nincs, vagy nem értelmezhetô.

Fontos probléma emellett, hogy mivel az intellektuális tôke összetevôi általában nem rendelkeznek materiális megjelenési formával, ezért értékük sokszor csak utólagos hatásuk elemzése révén becsülhetố. A becslési eljárás azonban rengeteg szubjektív elemet hordoz magában, ami egyrészt a mérési eredmények pontatlanságát okozhatja, másrészt a rendszer alkalmazottak általi elfogadottsága ellen is hathat.

Ezzel kapcsolatos, és elsôsorban a humán és kapcsolati tớke számbavétele során fellépó további nehézség, hogy a tudás, a tapasztalat, a kreativitás és más személyes jellemzók az egyénhez kötődnek, így legtöbbször indirekt módon megjelenó úgynevezett informális vagy tacit tudást jelentenek. Mivel azonban e tudáselem az emberek fejében létezik, így láthatóvá tétele - ha úgy tetszik formalizálása - meglehetósen nehéz, sok szempontból szinte lehetetlen vállalkozásnak bizonyulhat.
A fentiek mellett további nehézség az intellektuális tóke gyakorlati mérésével kapcsolatban, hogy nincs egy egységesen elfogadott értelmezési és módszertani keret a megvalósításra vonatkozóan, hiszen a gyakorlatban sokféle módszer létezik, amelyek - noha csak kismértékben, de - különböznek struktúrájukban, az alkalmazott mutatókban, illetóleg információtartalmukban. Mindez - kiegészülve a korábban említett definíciós sokszínúséggel - egyrészt lehetetlenné teszi a kutatási eredmények összehasonlítását és bárminemú általánosítását, másrészt csökkenti azt a tapasztalat- és információbázist, amelyre építve elkerülhetố lenne ugyanazon hibák elkerülése más-más vállalatok esetében.

$\mathrm{Az}$ egységes értelmezési keret hiánya, illetve az intellektuális tốke emberekhez (pl. tudás, tapasztalat, képességek stb.), illetve a szervezet más nehezen megragadható, puha jellemzóivel (pl. márka, vevókapcsolatok stb.) való szoros kapcsolata miatt szintén fontos kihívást jelent a mérés gyakorlatban történó megvalósitásának módja is. Csupán abból kiindulva, hogy minden mérés - egyszerúen a figyelem összpontosítása és az esetlegesen hozzákapcsolt javadalmazás révén - már önmagában is motivátor szerepet tölt be, a mérési célok és elvárások megfeleló kommunikációja és szisztematikus odafigyelés nélkül az érintettek körében könnyen negatív magatartási hatások (ezekról a késóbbiekben még lesz szó) léphetnek fel. Ezek legrosszabb esetben akár az elérni kívánt menedzsment színvonalbeli javulással ellentétes, a teljesítményt csökkentố szervezeti változásokat is kiválthatnak.

North, Probst és Romhardt a fenti általános és humán jellegú korlátok mellett további gyakorlati problémákat azonosít az intellektuális tốke különbözô mutatókkal történố leírása kapcsán. A szerzốk a mutató alapú (SC) módszereket vizsgálva a következő három problématerületet azonosítják (North - Probst - Romhardt, 1998):

- Nem azt mérik, ami fontos: a gyakorlatban elterjedt mérési módszerek, noha sok információt szolgáltatnak a nem tárgyiasult eszközökről, a fontos dolgokat mégsem mérik, azaz nem adnak kielégítő választ a piaci és könyv szerinti vállalatérték eltérésére, illetôleg nem, vagy csak részben mutatják be a siker szempontjából kritikus erőforrást, a tudást;

- Rosszat mérnek: a mérés során gyakran csupán aggregált pénzügyi mutatókra koncentrálnak, nem teszik egyértelmúvé az ok-okozati összefüggéseket, általában az egyszerúen mérhetô jellemzók mérésére kerül sor, illetve nem vizsgálják meg a mutatók relevanciáját sem;

- Rossz méröeszközöket, mutatókat alkalmaznak: a modellek általában előnyben részesítik a kvanti- 
tatív értékelést, és figyelmen kívül hagyják a kvalitatív tényezóket, valamint jellemzô a túl rövid időhorizont alkalmazása a mérés során.

Az elóbbiekhez hasonló eredményt hozott Ittner és Larcker empirikus tanulmánya is, amelyben a szerzópáros azt állítja, hogy a nem pénzügyi jellegú mutatók helytelen használatából származó károk akár az általuk elérhető hasznokat is felülmúlhatják. A szerzók a nem tárgyiasult erôforrások mérését célzó menedzsmenteszközök gyakorlati megvalósulását vizsgálva a következő négy fő problémát azonosítják (Ittner - Larcker, 2004):

- a mutatók és a stratégia összekapcsolásának hiánya;

- az (ok-okozati) összefüggések megerôsítésének elmulasztása;

- a helyes teljesítménycélok kijelölésének elmulasztása;

- a statisztikai érvényességet és megbízhatóságot nélkülöző helytelen mérés.

Látható tehát, hogy az intellektuális tôke mérése nem könnyú feladat. Mindazonáltal az immateriális eróforrások szervezeti értékteremtésben betöltött szerepe miatt menedzselésük, ezáltal pedig mérésük is elengedhetetlen. A következókben ezért a mérés során potenciálisan felmerülő magatartási kockázatokra hívom fel a figyelmet, amelyek hatékony kezelése jelentősen növelheti a megvalósítás sikerének esélyét.

\section{Az intellektuális tốke mérésének lehetséges magatartási vonatkozásai}

A nem tárgyiasult erőforrások mérését eddig elsősorban controllingfeladatként értelmeztük, melynek célja a vezetôi döntéshozatalhoz szükséges információ biztosítása és összehangolása. Tekintettel azonban arra, hogy az intellektuális tôke egyik legfontosabb hordozója a megfelelő képességekkel és tudással rendelkező motivált munkatárs, illetve elfogadva a rendszergondolkodás azon feltevését, miszerint minden emberi cselekvés - így a szervezetben lezajlók is - egymással szorosan összefüggố rendszert alkot, belátható, hogy az intellektuális tóke mérése nagy valószínúséggel közvetlen vagy közvetett hatással lesz a szervezeti tagok magatartására és teljesítményére is. Ezért a tudástôke mérésének sikeres gyakorlati megvalósítása érdekében nem hagyhatók figyelmen kívül azok a puhább, magatartási jellegú tényezók, amelyek adott esetben megkönnyíthetik, kezelésük hiányában azonban jelentősen megnehezíthetik a szellemi tókérôl szóló megbízható információk előállítását.
Megközelítésem szerint tehát még egy controllingszempontból tökéletesen megtervezett információs rendszer sem lehet sikeres az érintettek együttmúködése nélkül. A következókben ezért célom, hogy felhívjam a figyelmet az intellektuális tóke, illetve a humán tốke számbavétele és értékelése során potenciálisan jelentkező magatartási kockázatokra. A lehetséges magatartási hatásokat az emberieróforrás-menedzsment és a szervezeti magatartás szakirodalmában gyakran alkalmazott egyén-csoport-szervezet szerinti bontásban tárgyalom. A témakör szerteágazó jellege és e cikk mennyiségi korlátai miatt hangsúlyoznom kell azonban, hogy ehelyütt nem törekszem minden lehetséges magatartási tényezô teljes körú és részletes bemutatására, hanem csupán egyfajta ízelítőt és különböző feltevéseket szeretnék nyújtani, kiemelve a megvalósítás kritikus pontjait. Alapfeltételezésem szerint a magatartási kockázatok figyelmen kívül hagyása az elvárt pozitív teljesítményváltozással ellentétes eredményre vezethet, és összességében az egyéni, illetve szervezeti teljesítmény romlását is okozhatja.

\section{Egyéni szintü tényezók}

Valamennyi szervezet közös jellemzője, hogy csupán munkatársai révén lehet sikeres. A kívánt teljesítmény általában csak a képzett, tapasztalt és a szükséges képességekkel rendelkezó, motivált munkatársak kiválasztása és irányítása esetén érhetô el. A másik oldalról törekedni kell azonban az alkalmazottak részéról fellépó negatív viszonyulások, ellenállások, teljesítmény-visszatartások, valamint bármely olyan hatás elkerülésére, amelyek megakadályozhatják a célul túzött teljesítményelvárások teljesülését. Ehhez az alkalmazotti hiedelmek és értékek figyelembevétele, észlelésük és ítéletalkotásuk kedvezô irányba történô befolyásolása, valamint motivációjuk biztosítása elengedhetetlen.

HiedELMEK, ÉRTÉKEK, BEÁLlíTÓDÁs. Mindannyiunk valóságészlelését és -értelmezését, szervezeti és magánéleti cselekvéseit, valamint viselkedését befolyásolja személyiségünk (Kieser, 2003). Mivel hiedelmeink, értékeink és beállítódásunk fontos részei személyiségünknek, így nagymértékben befolyásolják magatartásunkat is. Ezáltal arra is jelentős hatással vannak, hogy a szervezet tagjai miként élik meg tudásukat, a szervezeti tudást, vagy más intellektuális tôkeelemeket számba vevố rendszerek bevezetését.

Fontos tehát megvizsgálni, hogy mi az érintettek hozzáállása tudásuk formális számbavételének gondolatához, a mérést megvalósító szervezeti rendszerhez vagy vezetôhöz, illetve mit gondolnak a tudás értékteremtő képességérôl az adott helyzetben és általában. A hiedelmek figyelembevételével olyan problémákat 
kerülhetünk el, mint pl. az alkalmazottak elôzetes félelme tudásuk számszerúsítése kapcsán, vagy a rosszindulatú szervezeti pletykák elterjedése. Abban az esetben pedig, ha az emberekben sikerül pozitív várakozásokat kialakítani a tudástóke mérésével kapcsolatban, az nemcsak az információs rendszer kialakítását és a mérés végrehajtását könnyítheti meg, hanem az alkalmazottak támogató hozzáállása miatt javulhat az előálló információk minősége és pontossága is, amely egyúttal növeli az információk felhasználhatóságát. Negatív attitűd esetén ezzel szemben egyéni és szervezeti elégedetlenség, illetve ellenállás kialakulásával számolhatunk, amelyek hosszú távon komoly teljesítménycsökkenést is okozhatnak.

ÉRZÉKELÉS, ÉSZLELÉs, ÍTÉLETALKOTÁs. A hiedelmek, értékek, beállítódások, valamint egyéb kontextuális tényezók alapján kerül sor a körülöttünk zajló események érzékelésére és észlelésére, valamint véleményünk megfogalmazására - ún. ítéletalkotásra - velük kapcsolatban. Míg azonban az érzékelés környezeti ingerek egyszerú érzékszervi megragadását jelenti, addig az észlelés és ítéletalkotás folyamatát számos magatartási tényező (pl. előzetes feltevések, érdekek, tapasztalatok, elvárások, figyelem, a szervezetben fennálló bizalom stb.) is befolyásolja, amelyek hatással vannak a szervezet tagjainak viselkedésére, így együttmúködési hajlandóságára is a tudástôke menedzsmentjével kapcsolatban (Bakacsi, 1996).

Mindez az intellektuális tóke mérésével kapcsolatban azt jelenti, hogy az alkalmazott módszerek, mutatók és a mérési folyamat alkalmazotti megítélése, szervezeti tagok általi - esetlegesen eltérô - észlelése jelentôs hatással lehet a mérôeszköz eredményességére, az érintettek viselkedésére, együttmúködésére, valamint hozzáállására is a bevezetendô információs rendszer vonatkozásában.

$\mathrm{Az}$ észlelés szerepe azonban legalább kétoldalú, hiszen mérés során egyrészt elsősorban az emberi eróforrásban rejlô tudást ragadjuk meg, másrészt magát a mérést és a kapott eredmények értelmezését is munkatársak végzik. Másképp megfogalmazva ez azt jelenti, hogy még ha az egyes munkatársak nem is tudnak arról, hogy különbözó mutatók segítségével a vállalat értékeli tudásukat és/vagy az általuk kialakított szervezeti folyamatokat, vevớkapcsolatokat, az eredmények eltérő munkatársi értelmezése és interpretálása révén akkor is hatással lehet a teljesítményre, a szervezetben uralkodó hangulatra, valamint a konfliktusokra egyaránt.

Motivéció. „Motivációról akkor beszélhetünk, ha hajlandóak vagyunk a szervezeti célok megvalósítása irányába mutató erófeszítésre, amellyel egyben egyéni szükségleteinket is kielégítjük" (Bakacsi, 1996: 82. o.).
A motiváció tehát egyfelól azt jelenti, hogy a munkatársak úgy érzik, nyertek valamit tevékenységük eredményeképpen, miközben a szervezet teljesítménye is nagyobb. Motiváció hiányában a szervezet tagjai nem rendelkeznek megfeleló belső késztetéssel a nagyobb erôfeszítés irányába, így egyéni hozzájárulásuk, valamint a szervezet teljesítménye is csökkenhet.

A motiváció kérdése, erőteljes teljesítménybefolyásoló hatása miatt, az intellektuális tốke számbavétele kapcsán is kiemelten kezelendő. Egyrészt törekedni kell arra, hogy a mérés ne csak a szervezet, hanem az egyének számára szintén fontos legyen, másrészt elő kell segíteni, hogy a munkatársak megtanulják a rendszer múködését is. Fontos odafigyelni emellett arra is, hogy ne romboljuk le az alkalmazottaknak a szervezet általános céljai irányába mutató egyéni motivációit, sôt, ha lehet, a mérés céljainak megértése, valamint a munkatársak bevonása révén növeljük is azokat. Mindez természetesen szisztematikus odafigyelést és folyamatos kommunikációt követel meg a vezetés részéról az intellektuális tốke tényleges állapotának megragadása, illetve a szervezeten belüli tudásmegosztás fejlesztése érdekében.

A szellemi tóke minél pontosabb számbavétele motivációs szempontból a mérés megbizó-ügynök jellege miatt is érdekes, hiszen az intellektuális tốke nem tárgyiasult jellege és nehéz nyomon követhetôsége következtében információs aszimmetria áll fenn a tudástókével rendelkezó munkatárs (ügynök) és a mérést megvalósító menedzser (megbízó) között. A gyakorlatban mindez azt jelenti, hogy az értékeltnek lehetósége van akár elrejteni, vagy akár túlbecsülni egyéni, illetve a szervezet intellektuálistóke-ellátottságát. Ez azonban felveti a rendszerból kinyert információk pontatlanságának veszélyét, amely egyúttal megkérdôjelezi azok felhasználhatóságát is.

Az információk felhasználása kapcsán felmerülő további motivációs szempont az is, hogy a vezetés ténylegesen használja-e majd a költségek árán felépitendó információs rendszerból elóálló adatokat. Másképp kifejezve: figyelembe veszik-e döntéseik során, és ha igen, milyen mértékben az intellektuális tốkéról szóló információkat. A szervezet tevékenységét, a korlátozott racionalitás létét, a menedzsment döntési preferenciáit és stílusát, valamint információs igényét figyelembe véve érdemes megvizsgálni tehát, hogy a menedzsereknek szükségük van-e egyáltalán, és ha igen, milyen formában az elóálló információkra, illetve valóban építenek-e rájuk a szervezet irányítása során. Fontos kiemelni azonban, hogy noha a vezetés preferenciái sok esetben meghatározhatják a felhasználandó információk körét, az ún. tudásintenzív iparágakban (pl. tanácsadás, szoftverfejlesztés, gyógyszeripar stb.) a fenti információk 
semmiképp sem hagyhatók figyelmen kívül, hiszen itt éppen a nem tárgyiasult eróforrások az alapvetô képesség legfontosabb és kiemelten kezelendő forrásai.

\section{Csoportszintü hatások}

A szervezet nem egymástól függetlenül tevékenykedő egyének halmaza, hanem tagjai közös érdekeiket felismerve, valamint interakciós és társas szükségleteik kielégítése érdekében egymással is kooperáló csoportokat, mai divatosabb nevén teameket hoznak létre. Az ilyen csoportok tagjai valamilyen közös céllal rendelkeznek, amely elérése érdekében a csoporttagok együttmúködnek, miközben azt várják, hogy előrelépés következik be az egyéni cél elérésében is. A múködés során a tagok emellett egymástól függő helyzetbe is kerülnek, hiszen minden egyes csoporttag tevékenysége hatással van a csoportra és a többi egyénre, míg a többi tag cselekvése szintén befolyásolja az egyént (Bakacsi, 1996; George-Jones, 1999).

Mivel a csoport és annak múködése hatással van a szervezeti tagok magatartására, a szellemi tóke mérése során a korábban bemutatott egyéni szintú befolyásoló tényezók kezelése mellett figyelemmel kell lennünk a szervezetet alkotó csoportokra, az óket érintő hatásokra, valamint a mérésben - akár a méró, akár a mért oldaláról - érintett egyének helyzetére és megelégedettségére az adott csoportban.

Mindazonáltal nem szabad figyelmen kívül hagyni azt sem, hogy a csoportteljesítményre, valamint az intellektuális tóke mérésének gyakorlati sikerére az itt tárgyaltakon kívül számos egyéb, a csoporton belülról, illetve azon kívülról érkezó befolyásoló tényezô (pl. a szervezet stratégiája, hatásköri viszonyok, a csoport feladata, erőforrások stb.) is hatást gyakorol. Mivel azonban ezek csoportszinten általában adottságnak tekinthetốk, így kezelésük a legtöbb esetben csupán szervezeti szinten valósítható meg.

A csoportszintú befolyásoló tényezőkkel kapcsolatban fontosnak tartom megjegyezni emellett azt is, hogy az itt bemutatott és csoportszinten kezelt hatások a legtöbb esetben szervezeti szinten is megjelennek, egyszerúen abból adódóan, hogy a szervezet önmagában is csoportnak tekinthetô. A csoport- és szervezeti szintû hatások elkülönítése így nem könnyú, és sok esetben csupán az adott helyzetben dönthető el.

KommuniKÁCió. Kommunikációnak azt a tevékenységet, folyamatot nevezzük, amikor két vagy több ember bizonyos szimbólumok segítségével információk, gondolatok cseréjére és közös értelmezésére törekszik. Ez lehet formális szervezeti információáramlás, de ide tartozik a szervezeti tagok között lezajló informális gondolatcsere is (Bakacsi, 1996).
A hatékony kommunikáció a szervezet fontos alkotóeleme, és a szervezet múködése szempontjából négyféle fố funkciót lát el: segítségével (1) információkhoz juthatunk a célokról, elvárt teljesítményról és magatartásról; fontos szerepe van a (2) motiváció tekintetében, hiszen kommunikációra van szükség egyes bonyolult célok megértéséhez, valamint általa kerül sor a visszajelzésre is; (3) az egyéni erófeszítések kontrollja és koordinációja szintén kommunikáció révén valósul meg; valamint a kommunikáció során (4) fejezzük ki érzéseinket, véleményünket a szervezetben lezajló eseményekkel kapcsolatban is (George - Jones, 1999).

Mivel a szervezetben minden esemény - cselekvés és nem cselekvés is - kommunikál, valamint mivel a tudástốke mérése a fenti négy aspektus mindegyikét érinti, a kommunikáció - csoport- és szervezeti szinten egyaránt - kiemelt fontosságú az intellektuális tôkét számszerúsító modellek megvalósításának sikere szempontjából.

A rendszer kialakításakor kiemelt figyelmet kell szentelni a mérési céloknak az érintett szervezeti tagok felé történó világos és egyértelmú kommunikációjá$r a$, hiszen enélkül nagyobb eséllyel alakulhatnak ki a korábban is említett félreértések, ellenállások, teljesítmény-visszatartások vagy más védekező mechanizmusok. Emellett a legtöbb esetben hasznos információkhoz juthatunk az alsóbb szintekról érkezó észrevételek figyelembevétele révén, illetve az érintett munkatársak részvételével a mérési-, és információs rendszer szervezeti elfogadottsága is javulhat, csupán abból adódóan, hogy bevonásuk miatt jobban magukénak érzik azt.

A kialakításkor alkalmazott kommunikáció fontosságán túl fontos mérlegelendô szempont az is, hogy egy intellektuális tốkét számba vevô rendszer bevezetése mennyiben változtatja meg a csoporton és a szervezeten belül korábban fennálló kommunikációs rendszert. A kommunikációs csatornák és szokások drasztikus megváltoztatása esetén ugyanis nagyobb valószínúséggel léphetnek fel negatív magatartási és teljesítményhatások (pl. félreértések, ellenállás, védekezố mechanizmusok stb.), amelyek kezelése a vezetóktốl a rendszer bevezetése kapcsán felmerülő amúgy is jelentôs változásvezetési tevékenység fokozását igényli.

Másik oldalról azonban a kommunikáció pozitív irányú változása adott esetben elősegítheti egy tudásés teljesítményorientált szervezeti kultúra kialakulását, valamint a nem tárgyiasult eróforrások szerepének hangsúlyozása révén elismerheti a bennük rejlő értékeket is. Emellett mivel az intellektuális tóke számbavétele során - legalább indirekt formában a munkatársak tudásának felmérése, a kritikus folyamatok leírása, vagy a vevốkapcsolatok elemzése révén - meghatároz- 
zák a vállalati értékteremtés szempontjából legfontosabb tudástőkeelemeket, a mérés eredményeinek szervezeti kommunikálása révén elősegíthetjük a szellemi tôke szervezeti szerepének javítását is.

VezeTÉSI sTílus. Az alkalmazottak közvetlen irányítása a kommunikáció mellett a vezetói tevékenység egyik legfontosabb összetevője. Célja az emberi erôforrás erőfeszítéseinek mozgósítása a szervezeti célok elérése érdekében. A vezetési stílus - amely leegyszerúsítve a személyes vezetés és a döntéshozatal módját, valamint a vezetô-beosztott viszony egyéb emberi kapcsolatokra jellemzố tényezôiinek összességét jelenti - jelentős hatással van az alkalmazottak motiváltságára, illetve hozzáállásukra a szervezetben bekövetkezô eseményekhez. A vezetố beosztottjaival szembeni viselkedése - mintegy mintaként - meghatározza az alkalmazottak viselkedését is (George-Jones, 1999).

A szervezetben tapasztalt vezetési stílus, a vezetôbeosztott viszony jellemzói, illetve vezetôk által korábban alkalmazott vezetói eszközök és kontroll jellege ebból adódóan nagymértékben befolyásolják az intellektuális tốkét számszerúsíteni igyekvő rendszerek sikeres múkködtetésének lehetôségét is, valamint a bevezetés szükséges módját, illetve a vezetôi részvétel mértékét is. Például egy korábban állandóan vezetối tekintélyét érvényesító vezetô sokkal kisebb eséllyel számíthat együttmúködésre és kezdeményezóképességre alkalmazottai részéról, mint egy beosztottközpontú, részvételi lehetôséget biztosító, az alkalmazottakat folyamatosan informáló, a felelősséget motiváló eszközként alkalmazó menedzser.

Hipotézisem szerint tehát korábbi kontrolleszközök alkalmazásának módja, a vezetôvel szembeni bizalom mértéke, valamint a bevezetésben és múködtetésben részt vevô vezetô személyisége jelentôs hatással lehet az alkalmazottak együttmúködési hajlandóságára a szellemi tốke számbavétele kapcsán, valamint nagymértékben befolyásolja a mérési rendszer által generált információk felhasználhatóságát is.

HATALOM. A hatalom képesség mások magatartásának hozzájárulásuk nélkül történô befolyásolására (Hunt, 1992). A hatalom tehát nem más, mint személyek és csoportok közötti dominancia vagy befolyás, amely számos szervezeti tényezó és egyéni jellemző esetén kialakulhat. Hatalom forrása lehet például a szúkösség, a helyettesíthetôség hiánya, a bizonytalanság, a karizmatikus személyiség, a tudás, vagy például bizonyos erőforrásokhoz való kizárólagos hozzáférés is (Robbins, 1998).

Mivel az információ a szervezeti hatalom egyik fontos forrása, az intellektuális tóke számbavételének mind a folyamata, mind pedig az eredménye befolyásolhatja a szervezet korábbi hatalmi eróviszonyait. Ennek oka, hogy a mérés során olyan szervezeti jellemzókról kapunk - jó esetben releváns - információt, amiról korábban - éppen nem tárgyiasult jellege miatt - nem, vagy csak kevés, esetenként pontatlan, becslésen alapuló adattal rendelkeztünk. A korábbi hatalmi szerkezet emellett jelentősen befolyásolhatja a tudástóke mérési rendszerének bevezetését is, hiszen a jelenleg hatalommal bírók nagyobb valószínúséggel állnak ellen egy olyan rendszer bevezetésének, amely adott esetben csökkentheti hatalmukat. A bevezetés elôtt a hatalmi struktúra és a potenciális hatalmi konfliktusok elemzése és a lehetséges hatások feltérképezése tehát elengedhetetlen.

STÁTus. A hatalmi szerkezet mellett érdemes lehet figyelembe venni azt is, hogy napjainkban sokszor a tudás, tágabb értelemben pedig az intellektuális tóke a szervezetben betöltött relatív pozíció - azaz a státus - legfő́bb meghatározója. Az egyéni tudásnak és képességeknek az intellektuális tóke számbavétele során kapott értéke, valamint az egyénnek csoportban, illetve a szervezetben betöltött státusa közötti kapcsolat elemzése ezért egyrészt fontos információkat szolgáltathat a nem tárgyiasult eróforrások értékteremtésben betöltött szerepéról, másrészt elkerülhetôvé teszi, hogy az egyének karrierlehetôségei korlátok közé szoruljanak csupán amiatt, hogy tudásuk egy adott időpontban történő méréskor egy adott értéket kapott (,,beskatulyázási veszély").

Mivel a magyar társadalom igen érzékeny a státusokra (Bakacsi, 1996), általam „,beskatulyázási veszélynek" nevezett hatás egyrészt alááshatja azt a sok esetben méltányolandó törekvést, miszerint az intellektuális tőke számbavétele fontos a szervezeti siker szempontjából, másrészt egyéb elkerülhető negatív hatásokat - például státusalapú kiinduló konfliktusokat, kiszolgáltatottságérzést, motiváció csökkenését stb. - is okozhat a szervezetben. A beskatulyázási hatás elkerülése tehát mindenképp ajánlott.

\section{Szervezeti szintü hatások}

A szervezet tagjai egyéni és csoporttevékenységük során természetesen nem légüres térben mozognak, magatartásukat számos olyan tényezố befolyásolja, amelyek csupán a szervezet egészét tekintve értelmezhetók. A szervezet tagjai által vallott értékek, a szervezeti szokások, illetve légkör mind-mind a teljesítményt befolyásoló tényezók.

SZERVEZETI KULTúRA. A szervezeti kultúra olyan értékek és normák informális halmaza, amelyek jelentősen befolyásolják, hogy a szervezet tagjai miként lépnek interakcióba egymással, valamint a szervezeten kívüli emberekkel (George - Jones, 1999). 
Másképp megfogalmazva: a szervezeti kultúra a szervezet tagjai által elfogadott, közösen értelmezett előfeltevések, értékek, meggyőzoódések, hiedelmek rendszerét jelenti, amely kifejezi a problémamegoldás követendő mintáit, valamint a szervezetben elvárt gondolkodás- és magatartásmódot. A kultúra kialakulása hosszú tanulási folyamat eredménye, amely során a szervezetben sikeresnek bizonyult megoldások pozitív megerôsítés révén szabályszerúséggé válnak, ezáltal csökken a bizonytalanság és növekszik a stabilitás (Bakacsi, 1996).

Mivel a szervezet kultúrája - a korábban tárgyalt egyéni hiedelmekhez, értékekhez hasonlóan - jelentósen befolyásolja az alkalmazottak szervezeti eseményekhez való hozzáállását, a szervezetben tapasztalható magatartást, valamint a teljesítményt is, így elemzése a tudástốke számbavétele kapcsán sem hagyható figyelmen kívül. Az intellektuális tóke mérésének a szervezeti kultúrába történó illesztésének/illeszkedésének szükségességét megerősíti emellett a kultúra megváltoztatásának meglehetôsen nehéz és idóigényes volta, amelyek miatt a szervezeti kultúra egy adott pillanatban adottságnak tekinthetô.

A szervezeti kultúra és a tudástóke mérésének kapcsolatát más oldalról tekintve felmerül a fenti mellett egy további aspektus is. Mégpedig annak a vizsgálata, hogy a szellemi tóke számbavétele és az arra létrehozott - kvantitatív mutatókat és kvalitatív értelmezéseket, értékeléseket - magába foglaló rendszer képes-e - és ha igen, mennyiben - kialakítani és támogatni egy olyan szervezeti kultúrát, amelyben az intellektuális tóke az értékteremtésben elfoglalt helyének megfelelöen egyre nagyobb hangsúlyt kap. Azaz a tudástóke mérése olyan megoldásnak minôsül-e a szervezetben, amely pozitív megerôsítése révén ,informális szabályszerúséggé”, azaz a kultúra elemévé válik.

A kultúra szerepe tehát legalább kétoldalú. „A kultúra egyrészt lehet olyan kedvezó alap, amelyet a vezetốk a szervezeti tagok jövóbeli cselekvéseinek fontos vezérlóeszközeként alkalmazhatnak, de lehet olyan negatív, visszahúzó erố is, ami új, megváltozott feltételrendszerben is korábbi, kedvezôtlen magatartásokat tart fenn, konzervál" (Bakacsi - Takács, 1998: 15. o.). Másképp megfogalmazva kijelenthetô, hogy míg a mérést támogató szervezeti kultúra megkönnyítheti, addig egy azt kevéssé, vagy nem támogató kultúra jelentős mértékben megnehezítheti a rendszer kialakítását, múködtetését, valamint olyan nem várt szervezeti ellenállásokhoz vezethet, amelyek a kulturális illeszkedés előzetes vizsgálatával elkerülhetốk, de legalábbis csökkenthetők lettek volna.

A kérdés magyarországi relevanciáját megerősíti emellett az is, hogy noha a hazai szervezetek kultúrá- jában a '90-es évek végéig a drámai változások lezajlottak, a vállalati kultúrában néhol még napjainkban sem - vagy nem megfelelő mértékben - lelhetô fel az a szintú teljesítményorientáció, amely a versenypiacon való megélhetéshez, és még inkább a sikerhez szükséges lenne (Bakacsi - Takács, 1998; Mármarosi, 2002). Hipotézisem szerint ez kifejezetten érvényes lehet a közigazgatás és a közszolgáltatások területére, ahol gyakran kormányzati tulajdonban, illetve állami felügyelet mellett múködő szervezetekkel vagy azok utódvállalataival találkozhatunk. Ilyen esetekben a tudástốke hatékony méréséhez sok esetben a szervezeti kultúra jelentôs megváltoztatása is szükséges lehet.

\section{Összegzés}

Noha a szakirodalomban a téma gyakorlati relevanciáját tekintve megoszlanak a vélemények, az előzőek alapján belátható, hogy az elmúlt években, évtizedekben jelentôs társadalmi, gazdasági és technológiai átalakulások zajlottak és zajlanak ma is, amelyek részben megváltoztatták a sikeres szervezetekról alkotott fogalmainkat. Ennek egyik megjelenési formája a nem tárgyiasult erôforrások arányának robbanásszerú növekedése az értékteremtésben és a szervezeti élet más területein. A kialakult helyzet egyre inkább megköveteli az intellektuális tôkeelemek hatékony menedzsmentjét és a szervezeti irányításba való eredményes beemelését. Mivel azonban mindez a nem tárgyiasult erőforrásokról szóló megbízható információk nélkül elképzelhetetlen, az intellektuális tốke számbavétele a nem tárgyiasult eróforrások menedzsmentjének előfeltételét jelenti.

Annak ellenére azonban, hogy a szakirodalomban többféle menedzsmenteszköz, illetve egymás mellett éló modellkísérlet is született a nem tárgyiasult eróforrások számbavétele kapcsán, nem alakult ki egységes nyelvezet a megvalósításra vonatkozóan. A mérés gyakorlati megvalósítása korántsem egyszerú feladat. Ez egyrészt a tudástóke nem tárgyiasult jellegéból következik, valamint a megvalósítás során gyakran figyelmen kívül hagyott olyan magatartási jellegú kockázatokból, amelyek nagyobb odafigyeléssel sokszor elkerülhetốk lennének. Éppen ezért írásom legfőbb célja - az intellektuális tốke számszerúsítését szolgáló fóbb módszerek bemutatása mellett - azon lehetséges magatartási tényezók azonosítása volt, amelyek befolyással lehetnek az intellektuális vagyon számbavételének szervezeti fogadtatására, a mérés során elóálló információk minőségére és felhasználhatóságára, valamint tényleges alkalmazására a vezetôi döntéshozatal színvonalának javítása érdekében. 
Hozzá kell tennem azonban, hogy az itt megfogalmazott magatartási hatások korántsem tekinthetôk általános érvényúnek, és a felvázolt kockázatok a kontextus (pl. iparág, tevékenység, környezeti kihívások) függvényében valószínúleg más-más módon jelentkezhetnek. Sót az itt bemutatott - controlling és magatartási - tényezốk nagy valószínúséggel számos további szemponttal (pl. változáskezelés kérdése, közgazdasági és vállalatértékelési kihívások) is kiegészíthetôk, melyek további érdekes kutatási irányokat nyithatnak meg a szellemi tốke számbavétele kapcsán.

\section{Lábjegyzet}

1 A szerzó okleveles közgazdász, az IFUA Horváth \& Partners Kft. tanácsadója, a szervezet Controlling Kompetencia Központjának tagja. E-mail: tamas.

${ }^{2}$ Dankó Dávid - Kiss Norbert - Tirnitz Tamás: A Balanced Scorecard módszertani alternatívái. Menedzsment Kontroll Információrendszerek előadás, Budapesti Corvinus Egyetem, Vezetés és Szervezés Tanszék, 2005-09-29.

\section{Felhasznált irodalom}

Andriessen, D. (2004): Making Sense of Intellectual Capital. Designing a Method for the Valuation of Intangibles. Elsevier Butterworth-Heinemann, Amsterdam (etc.)

Arbeitskreis IWR (2001): Kategorisierung und Bilanzielle Erfassung immatieller Werte. Arbeitskreis „Immaterielle Werte im Rechnungswesen" der SchmalenbachGesellschaft für Betriebswirtschaft e. V., Der Bertieb, Heft 19., május 11., 989-995. o.

Bakacsi Gy. (1996): Szervezeti magatartás és vezetés. KJKKerszöv, Budapest

Bakacsi Gy. - Takács S. (1998): Honnan - hová? A nemzeti és szervezeti kultúra változásai a kilencvenes évek közepének Magyarországán. Vezetéstudomány, 29. évf., 2. szám, február, 15-22. o.

Brennan, N. - Connell, B. (2000): Intellectual Capital: current issues and policy implications. Journal of Intellectual Capital, Vol. 1, No. 3, 206-240. o.

Bontis, N. (2001): Assessing knowledge assets: a review of the models used to measure intellectual capital. International Journal of Management Reviews, Vol. 3, Issue 1, 41-60. o.

Edvinsson, L. (2002): Corporate Longitude. What you need to navigate the knowledge economy. Financial Times - Prentice Hall, London (etc.)

George, J.M. - Jones, G. R. (1999): Understanding and Managing Organizational Behavior. Addison-Wesley, New York (etc.)

Gu, F. - Lev, B. (2001): Intangible assets - measurement, drivers, usefulness. Boston Universitiy and New York Univerity. http://pages.stern.nyu.edu/ blev/intangibleassets.doc Letöltve: 2006-09-06.
Günther, T. - Neumann, P. (2004): Kennzahlen zur Berücksichtigung des Humankapitals. CM controller magazin, 4. szám, 362-369. o.

Gyökér I. (2004): A vállalat szellemi tókéje - számolatlan vagyon. Harvard Business Manager, 6. szám, 48-58. o.

Hunt, J. W. (1992): Managing People at Work: A Manager's Guide to Behaviour in Organizations. McGraw-Hill Book Company, London (etc.)

Ittner, C. - Larcker, D.F. (2004): A nem pénzügyi jellegú teljesítménymérés hiányosságai. Harvard Business Manager, június. 16-23. o.

Juhász P. (2004): Az üzleti és könyv szerinti érték eltérésének magyarázata - Vállalatok mérlegen kívüli tételeinek értékelési problémái. Doktori (PhD) értékezés, Budapesti Corvinus Egyetem, Gazdálkodástudományi Kar, Gazdálkodási Doktori Iskola

Kaplan, R.S. - Norton, D.P. (1996): Balanced Scorecard - Eszköz, ami mozgásba hozza a stratégiát. Magyar kiadás: KJK-Kerszöv, Budapest

Kaplan, R. S. - Norton, D. P. (2005): Stratégiai térképek. Hogyan alakulnak át az immateriális javak pénzügyi eredménnyé? Panem Kiadó, Budapest

Kaufmann, L. - Schneider, Y. (2004): Intangibles - A synthesis of current research. Journal of Intellectual Capital, Vol. 5, No. 3, 52-63. o.

Kieser, A. (2003): Szervezetelméletek. Budapesti Közgazdaságtudományi és Államigazgatási Egyetem, Vezetésszervezés Tanszék, Budapest

KPMG-BME Akadémia - Pannon Egyetem (2006): Tudásmenedzsment Magyarországon 2005/2006. KBA Oktatási Kft., Budapest. http://www.doc.hu/tm/tmriport2005. pdf Letöltve: 2006-10-28.

Lev, B. (2003): Accounting for intangibles. Előadás a New York University-n, 2003. április. http://pages.stern.nyu. edu/ blev/teaching/Accounting\%20for\%20Intangibles. ppt\#371,1,ACCOUNTING FOR INTANGIBLES Letöltve: 2006-09-06.

Lev, B. (2004): Az immateriális javakban rejlő versenyelőny fokozása. Manager Magazin, December, 39-47. o.

Mármarosi A. (2002): Szervezetikultúra-típusok a '90-es évek végén Magyarországon. Vezetéstudomány, 33. évf., 6. szám június 2-16. o.

Mouritsen, J. - Bukh, P. (2003): Getting the measure of knowledge. Chartered Institute of Management Accountants. http://www.cimaglobal.com/cps/rde/xchg/ SID-0AAAC564-5F618CD3/live/root.xsl/6384_6995. htm Letöltve: 2005-10-01.

Mouritsen et al. (2003): Intellectual Capital Statements - The new guideline. Danish Ministry of Science, Technology and Innovation, február

North, K. - Probst, G. - Romhardt, K. (1998): Wissen messen - Ansätze, Erfahrungen und kritische Fragen. Zeitschrift Führung + Organiation (ZFO-Magazin), 3. sz., 158-166. o. Pfeil, O.P. (2004): Earnings from Intellectual Capital as a Driver of Shareholder Value. Haupt Verlag AG, Bern 
Prahalad, C.K. - Hamel, G. (1990): The Core Competence of the Corporation. Harvard Business Review, MayJune, 79-91. o.

RICARDIS (2005): Reporting Intellectual Capital to Augment Research, Development and Innovation in SMEs. EndReport, Introduction \& Part 1, Version July 15 th

Robbins, S. P. (1998): Organizational Behavior - Concepts, Controversies, Applications. Prentice-Hall International, New Jersey

Schönleber, C. (2005): Wissensbewertungsmethoden. http:// www.schoenleber.org/wbm.pdf Letöltve: 2006-09-22.

Skandia (1999): Skandia Annual Report 1999. http://www. euroland.com/pdf/S-SDIA/AR_ENG_1999_1.pdf Letöltve: 2006-09-18.

Starovic, D. - Marr, B. (2003): Understanding corporate value: managing and reporting intellectual capital.
Cranfield University School of Management, Chartered Institute of Management Accountants http://www. cimaglobal.com/cps/rde/xbcr/SID0AAAC56497A2B 7C7/live/MgRptIntCap_techrpt_2003.pdf Letöltve: 2006-09-15.

Sveiby, K.E. (2001a): A knowledge-based theory of the firm to guide in strategy formulation. Journal of Intellectual Capital, Vol. 2, No. 4, 344-358. o.

Sveiby, K.E. (2001b): Szervezetek új gazdagsága: a menedzselt tudás. KJK-Kerszöv, Budapest

Sveiby, K.E. (2001c): The Intangible Assets Monitor. http:// www.sveiby.com/Portals/0/articles/CompanyMonitor. html Letöltve: 2006-09-19.

Cikk beérkezett: 2007. 3. hó

Lektori vélemény alapján átdolgozva: 2007. 5. hó

\title{
Felhívás elöadás tartására \\ a 2008-as Ipar- és Vállalatgazdasági Konferencián
}

\author{
Az MTA IX. Osztály Ipar- és Vállalatgazdasági Bizottsága - a Szegedi Egyetemmel \\ és további társrendezőkkel együttmüködve
}

\section{8. október 30-31-én Szegeden}

rendezi a IX. Ipar- és Vállalatgazdasági Konferenciáját. A rendezvény fő témája

\section{„A gazdasági környezet és a vállalati stratégiák”}

A rendezvényre előadók jelentkezését kérjük. A jelentkezéseket - az előirányzott maximum 2 oldalas előadás vázlatának mellékelésével - 2008. március 1-jéig kérjük az ipari2008@gmail.com címre megküldeni.

A konferencián meg szeretnénk őrizni a korábban kialakult - s legutóbb 2004-ben Pécsett is sikeresnek bizonyult - hagyományokat. A jelentkezőktől azt kérjük tehát, hogy előadásukban a választott (a tudományterülethez sorolható) tárgykörben a nemzetközi tendenciákról és/vagy a hazai helyzetről (is) adjanak képet, mondanivalójukat empirikus kutatásokra építsék, és eredményeiket vessék össze a gyakorlattal. Az előirányzott szekciók a következők:
1. versenyképes környezet és gazdálkodás;
2. vállalkozás és kkv-k;
3. kutatás-fejlesztés, innováció;
4. tulajdonosi, vállalati érték és vállalati pénzügyek;
5. vállalatvezetés, regionális fejlődés, iparszerkezeti változások,
6. PhD-szekció (a második évüket a konferenciáig befejező hallgatók számára).

A beküldött jelentkezések elfogadásáról programbizottság dönt, döntéséről 2008. április 30-áig mindenkinek értesítést küld, s az elfogadott előadásokat szekciókba sorolja. Az előadóktól 2008. június 1-jéig kérjük az előadás 8-10 oldalas írásos kifejtését. Ezeket (szerkesztést követően) elektronikusan nyilvánosságra hozzuk, s ha a finanszírozást meg tudjuk oldani, könyv formájában is közreadjuk. A konferencia részvételi díja $40.000 \mathrm{Ft}$ (a bizottság tagjainak $30.000 \mathrm{Ft}$ ).

A bizottság jutalmat ír ki a legjobb előadás számára. A PhD-szekció legjobb előadását szintén díjazzuk. A díjak odaítéléséről bíráló bizottság dönt. 